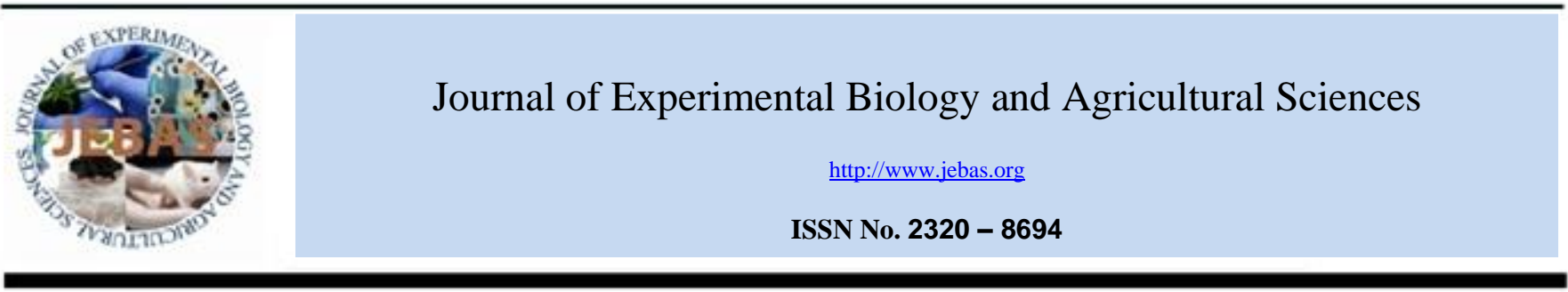

\title{
BATS: CARRIERS OF ZOONOTIC VIRAL AND EMERGING INFECTIOUS DISEASES
}

\author{
Koushlesh Ranjan ${ }^{1, *}$, Minakshi Prasad ${ }^{2}$ and Gaya Prasad ${ }^{3}$ \\ ${ }^{1}$ Department of Veterinary Physiology and Biochemistry, Sardar Vallabhbhai Patel University of Agriculture and Technology, Meerut, India, 250110 \\ ${ }^{2}$ Department of Animal Biotechnology, LLR University of Veterinary and Animal Sciences, Hisar, Haryana, India, 125004 \\ ${ }^{3}$ Sardar Vallabhbhai Patel University of Agriculture and Technology, Meerut, Uttar Pradesh, India, 250110
}

Received - April 18, 2016; Revision - May 05, 2016; Accepted - May 21, 2016

Available Online - May 25, 2016

DOI: http://dx.doi.org/10.18006/2016.4(3S).291.306

\begin{abstract}
KEYWORDS
Bat

Reservoir host

Vector

Zoonosis

Emerging infectious disease

ABSTRACT

Bats are reported as reservoir host for several viruses, which cause significant illness in human and animals. Some of the bat transmitted zoonotic viral diseases such as Ebola, Hendra, Nipah and rabies may cause severe human casualties. They also harbor several other viruses such as MERS and SARS corona viruses, which may cause disease in human through direct spillover to human or through an intermediate host or vectors. Being reservoir hosts bats do not get affected by these viruses. This probably may happen due to the specificity of bat immune system, which reacts differently with viral pathogens in comparison to their other mammalian counterparts. Although bats are important reservoir hosts for several zoonotic viruses, very little information is available regarding host/virus relationships as only few experimental studies have been done on bat colonies, lack of expertise for study of bat immunology and antiviral responses and difficulty in conducting field work. However, with the advancement in epidemiology and molecular biology, these problems can be addressed, which will provide the insight into interactions of bats and zoonotic viruses. It may also clarify regarding virus persistence in nature and various associated risk factors which might facilitate viral transmission to animals and humans.
\end{abstract}

* Corresponding author

E-mail: drkoushleshranjan@gmail.com (Koushlesh Ranjan)

Peer review under responsibility of Journal of Experimental Biology and Agricultural Sciences.

Production and Hosting by Horizon Publisher India [HPI] (http://www.horizonpublisherindia.in/).

All rights reserved.
All the article published by Journal of Experimental Biology and Agricultural Sciences is licensed under a Creative Commons Attribution-NonCommercial 4.0 International License Based on a work at www.jebas.org.

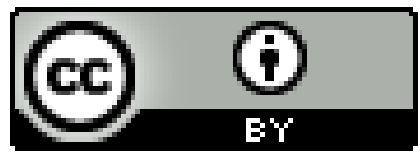




\section{Introduction}

Bats are the most diverse, abundant and geographically dispersed member of vertebrate family. Despite enough information since ancient age, still reliable information is required to explain the diversity in their lifestyle, anatomy, role in ecosystems ecology and as reservoir hosts for viruses of medical and veterinary importance. Bats can survive in diverse climate. They are found in all continents except Antarctica. Different bat species may feed on several food materials such as mammals, blood, insects, fish, pollen and fruit. Bats are also recognized as reservoir hosts for several zoonotic viruses which can infect humans and animals (Hayman et al., 2013). Although they can transmit several zoonotic viruses, they are also valuable elements of terrestrial biotic communities. They play a significant role in insect control, pollination of plants and reseed the cut forests which are essential for survival of human and animal life (Hill \& Smith, 1984; Kunz \& Fenton, 2003).

Bats harbor a range of emerging infectious viral pathogens. Many of such emerging infectious diseases (EIDs) are zoonotic in nature (Woolhouse \& Gowtage-Sequeria, 2005; Jones et al., 2008; Dhama et al., 2013). In developing countries, the zoonotic viral infections especially caused by RNA viruses such as rabies, Ebola etc. have been recognized as significant threats for human health (Maudlin et al., 2009; Dhama et al., 2015). In addition to rabies and other lyssaviruses (Streicker et al., 2010), bats have also been reported as reservoir hosts for several other viral pathogens such as Hendra virus $(\mathrm{HeV})$ (Halpin et al., 2000; Edson et al., 2015), severe acute respiratory syndrome-coronavirus (SARS- $\mathrm{CoV}$ ) (Li et al., 2005; Vijaykrishna et al., 2007), Ebola virus (EBOV) (Leroy et al., 2005), Nipah virus (NiV) (Chua et al., 2002a; Chua et al., 2002b; Reynes et al., 2005) and Marburg virus (MARV) (Peterson et al., 2004; Towner et al., 2007). In USA, a new lineage of influenza A virus has also been reported from little yellow shouldered bats (Sturnira lilium) (Tong et al., 2012). Several other Paramyxoviruses have also been reported from bats from various regions of the globe (Drexler et al., 2012). Since, bats are reported as reservoirs for several viral EIDs (Table 1), it is crucial to understand that how bat ecology may influence zoonotic disease outbreaks and their role as reservoirs for emerging viral pathogens (Messenger et al., 2003; Calisher et al., 2006; Wong et al., 2007; Hayman et al., 2013). Several new viral pathogens are identified in bats every year which need to be characterized for their zoonotic potential to human population. Most of such studies are mainly focused on zoonotic infectious diseases of medical and veterinary importance.

This review paper is focused on bat associated zoonotic viruses causing diseases to animals and human. Several bat species play important role in maintenance and transmission of zoonotic viruses which explains the requirement of special consideration for characterization of bats from other mammals.

\section{Bat Immunology}

It is observed that several viruses which are highly pathogenic for human and animals can infect and persist in healthy bats without causing significant harm to them. Possibly it may be due to the fact that bats were evolved earlier among mammalian species and their acquired and innate immune responses have significant differences from other animal species such as rodents and primates. It is also assumed that bat's immune system react differently with pathogens which lead to control virus replication with persistence of infectious virus in bat tissues (Schountz, 2014). This results in prevention of immunopathological responses in infected bat tissues. However, within several bat species significant differences in immune responses against viral infection may be found.

Although very little is known about bat immunology, several studies have shown that bat immune responses also have some similarities with mammals that evolved after bats. Several immunoglobulin classes such as $\operatorname{IgG}, \operatorname{IgA}$, and $\operatorname{IgM}$ found in mammals have also been purified from great fruit-eating bat (Artibeus lituratus) sera (McMurray et al., 1982). The lymphoid development of bats and other mammals are also very similar which is evidenced by identification of $\mathrm{B}$ and $\mathrm{T}$ lymphocytes, Macrophages and cells expressing surface Ig in bone marrow of Indian bats (Pteropus giganteus) (Schountz et al., 2004). The serological assays against several viruses such as severe acute respiratory syndrome-coronavirus (SARS$\mathrm{CoV}$ ) like viruses, Hendra virus and Ebola virus in bats (Lau et al., 2005; Leroy et al., 2005) indicate that virus specific adaptive $\mathrm{B}$ and $\mathrm{T}$ cell responses might occur despite persistent virus infection. However, further study is required to understand the mechanism of antibody synthesis, cytokine synthesis, lymphocyte proliferation etc. in bats.

\section{Zoonotic viruses in bats}

Bats harbor several viruses as reservoir host. Many of these viruses have not been reported to transmit from bats to human or other mammals. However, several viruses of bats such as Nipah and Hendra virus, rabies virus and related lyssaviruses, SARS-CoV-like virus etc may be transmitted to human and animals and lead to highly pathogenic disease (Table 1). Some other viruses such as certain flaviviruses, alphaviruses and bunyaviruses may also infect bats via vectors. However, it is not established that whether bats act as important reservoir hosts for such viruses.

\subsection{Rabies Virus}

A lot of scientific information is available regarding rabies virus, its transmission and pathogenesis in human and animals. Rabies was described in ancient literature in around 4000 years ago. However, its scientific study started in late 19th century. Louis Pasteur amplified the rabies virus in spinal cord of rabbit and prepared vaccine for post exposure prophylaxis. 
Table 1 Zoonotic viruses causing disease in human and their bat reservoir hosts.

\begin{tabular}{|c|c|c|c|c|}
\hline S. No. & Disease & Virus & Reservoir Host & References \\
\hline 1 & Rabies & $\begin{array}{l}\text { Rabies virus and other } \\
\text { lyssaviruses }\end{array}$ & $\begin{array}{l}\text { Several bat species distributed world } \\
\text { wide }\end{array}$ & $\begin{array}{l}\text { Rupprecht } \\
\text { et al., 1995; Calisher et } \\
\text { al., 2006; López-Roig et } \\
\text { al., } 2014\end{array}$ \\
\hline 2 & Ebola virus disease & Ebolaviruses & $\begin{array}{l}\text { Franquet's epauletted fruit bat (Epomops } \\
\text { franqueti), Hammer headed bat } \\
\text { (Hypsignathus monstrosus), little } \\
\text { collared fruit bat (Myonycteris torquata) }\end{array}$ & Leroy et al., 2005 \\
\hline 3 & $\begin{array}{l}\text { Marburg } \\
\text { disease }\end{array}$ & Marburg virus & $\begin{array}{l}\begin{array}{l}\text { Egyptian fruit bat } \\
\text { aegyptiacus) }\end{array} \\
\end{array}$ & Towner et al., 2007 \\
\hline 4 & $\begin{array}{l}\text { Middle east } \\
\text { respiratory syndrome }\end{array}$ & MERS-CoV & $\begin{array}{l}\begin{array}{l}\text { Egyptian tomb bat } \\
\text { perforatus) }\end{array} \\
\end{array}$ & Memish et al., 2013 \\
\hline 5 & $\begin{array}{l}\text { Severe acute } \\
\text { respiratory syndrome }\end{array}$ & SARS-CoV & $\begin{array}{l}\text { Chinese horseshoe bat (Rhinolophus } \\
\text { spp.) }\end{array}$ & Lau et al., 2005 \\
\hline 6 & $\begin{array}{l}\text { Severe acute febrile } \\
\text { disease }\end{array}$ & Sosuga virus & Rousettus spp. & $\begin{array}{l}\text { Albarino et al., 2014; } \\
\text { Amman et al., 2015b }\end{array}$ \\
\hline 7 & Encephalitis & $\begin{array}{l}\text { Nipah and Hendra } \\
\text { viruses }\end{array}$ & Some flying foxes (Pteropus spp.) & $\begin{array}{l}\text { Chua et al., 2002; } \\
\text { Halpin } \\
\text { et al., } 2000\end{array}$ \\
\hline 8 & Encephalitis & Tioman virus & Pteropus hypomelanus & $\begin{array}{l}\text { Chua et al., 2001; Yaiw et } \\
\text { al., } 2008\end{array}$ \\
\hline 9 & $\begin{array}{l}\text { Menangle } \\
\text { disease }\end{array}$ & Menangle virus & $\begin{array}{l}\text { Little red flying foxes and gray headed } \\
\text { flying foxes }\end{array}$ & $\begin{array}{l}\text { Philbey et al., 1998; Barr } \\
\text { et al., } 2012\end{array}$ \\
\hline
\end{tabular}

Rabies virus belongs to the family Rhabdoviridae, genus Lyssavirus and transmitted between several mammals, including bats. Rabies transmission is primarily mediated by bite inoculation of virus available in saliva of rabies infected individuals. Three species of bats viz. Diaemus youngi (whitewinged vampire bat), Diphylla ecaudata (hairy-legged vampire bat) and Desmodus rotundus (vampire bat) have been reported to be involved in rabies transmission. However, further studies have shown that mainly Desmodus rotundus (vampire bat) is important in rabies transmission (Turner, 1975; Anderson et al., 2014). In USA, bats have been reported as reservoir vector in over $90 \%$ of human rabies cases. Among bats tricolored bat (Perimyotis subflavus) are reported as major reservoir host (Gilbert et al., 2015). The bat rabies virus variants isolated from Latin America in free tailed bats (genus Tadarida) and vampire bats (Desmodus rotundus) have been found to be close to earliest rabies virus. The study also suggest that adaptation of rabies virus in bats occurred earlier in colonial genera (Myotis and Eptesicus) than in bats of solitary genera (Pipistrellus, Lasionycteris, and Lasiuris) (Hughes et al., 2005).

Globally, approximately 55,000 annual human deaths are caused by rabies virus which can be associated with bats (Knobel et al., 2005). Rabies viruses of bat origin may sporadically spill over to infect human and other mammals. It has been reported in USA that most rabies victims do not recall the incidence of bitten by bat. This may be due to unusual circumstances during bat bite or being small size of the biting animal (Rupprecht et al., 2004). Recent studies also suggest that all rabies virus variants affecting terrestrial carnivores might be originated from cross-species transmission and genetic exchange from bat associated rabies virus.

\subsection{Other lyssaviruses}

Bats are also reservoir for several other lyssaviruses including Duvenhage virus (DUVV), Shimoni bat virus (SHIBV), Irkut virus (IRKV), West Caucasian bat virus (WCBV), Australian bat lyssavirus (ABLV), European bat lyssavirus 1 (EBLV-1) and European bat lyssavirus 1 (EBLV-2). EBLV-1 and EBLV2 are reported in Europe from Eptesicus fuscus and Myotis spp of bat respectively. Some of the sporadic cases of human rabies have been reported from EBLV-1 and EBLV-2 (Kuzmin \& Rupprecht, 2007; Kuzmin et al., 2011). However, in terrestrial mammals some of the sporadic cases of EBLV-1 infection were also reported which might be a potential source for human exposure (Dacheux et al., 2009). In France, neutralizing antibodies against EBLV-1 were detected in six species (Pipistrellus pipistrellus, P. kuhlii, Hypsugo savii, Plecotus austriacus, Eptesicus serotinus and Tadarida teniotis) of bats (López-Roig et al., 2014). Recently, in Germany, EBLV-1 and EBLV-2 were detected from Eptesicus serotinus and Myotis daubentonii bat species (Schatz et al., 2014). The complete genome sequences of EBLV-1 have been extracted from Eptesiscus isabellinus bat in Spain (Marston et al., 2015).

Some of the insectivorous bat species such as Murina leucogaster harbor IRKV (Botvinkin et al., 2003). IRKV may also cause human rabies. IRKV was reported from a human rabies case in Russia. The human patient was a victim of an 
insectivorous bat bite (Leonova et al., 2010). Some of the suspected human rabies cases caused by IRKV were also detected in Ukraine and China (Botvinkin et al., 2006).

IRKV was also first time isolated in China from brain of northeastern bat (Murina leucogaster) which showed maximum nucleotide and amino acid identity with IRKV isolated from Russia. Virus produced rabies like symptoms in adult mice (Liu et al., 2013a). On experimental pre-exposure prophylaxis (PrEP) and postexposure prophylaxis (PEP) analysis with rabies vaccine against IRKV in hamster model showed that routine PrEP with three doses of vaccine may generate complete protection. However, for complete protection from IRKV higher doses of PEP agent such as anti-rabies immunoglobulins are required (Liu et al., 2013b).

The WCBV was isolated in south-eastern Europe from insectivorous bat Miniopterus schreibersii. Since, WCBV are most divergent Lyssavirus, all the anti-rabies biological are inefficient in providing protection against this virus (Hanlon et al., 2005). Although, the public health significance and ecology of WCBV is still unknown, the experimental infection in bats and laboratory animals, developed typical rabies symptoms which led to death (Kuzmin et al., 2008).

Other member of Lyssavirus, SHIBV was also isolated from a bat (Hipposideros commersoni) (Kuzmin et al., 2011). The biological significance of SHIBV for public health is unknown. However, they may cause pathogenesis in experimentally infected laboratory animals, which develop rabies and finally die (Markotter et al., 2009; Kuzmin et al., 2010). Due to their antigenic differences, current rabies biologicals cannot protect from SHIBV (Hanlon et al., 2005).

DUVV also causes dreadful human rabies in Africa. Despite availability of anti-rabies biological, it still causes human casualties because of inadequate knowledge of disease. Some of insectivorous bat species such, Miniopterus sp may transmit DUVV to human (Markotter et al., 2008). In 2007, a Dutch tourist was bitten by a bat in Kenya. The patient was allowed for medical help. However, due to lack of adequate anti-rabies PEP administration, rabies symptom was developed and patient died from DUVV infection (van Thiel et al., 2009; Koraka et al., 2012).

The ABLV was discovered in 'rabies-free' Australia in 1996. The ABLV was identified first in black flying fox (Pteropus alecto) (Fraser et al., 1996). Now, it is assumed that all bats in Australia may potentially carry ABLV (http://www.health.nsw.gov.au/). Later on, it was reported that some of the insectivorous bat species such as Saccolaimus flaviventris may also harbour ABLV (Gould et al., 2002). Two fatal human cases of ABLV infection with clinical symptoms compatible with rabies have been detected (Gould et al., 2002; Warrilow et al., 2002).

\subsection{Henipavirus (Hendra and Nipah virus)}

An outbreak of acute respiratory illness was reported in human and horses during 1994 to 2004 in Hendra, Australia (Field et al., 2011). The etiological agent reported was from genus Henipavirus and family Paramyxoviridae. Later on it was named as Hendra and Nipah virus (Murray et al., 1995). Several bat species such as fruit bats (flying foxes) of the genus Pteropus, including gray headed flying fox (Pteropus poliocephalus), black flying fox (P. alecto), spectacled flying fox (P. conspicillatus) and little red flying fox (P. scapulatus) were reported as probable reservoir hosts of Hendra virus (Field et al., 2011; Wang et al., 2013). The qRT-PCR assay showed that $\mathrm{P}$. alecto is potent reservoir host than $\mathrm{P}$. poliocephalus and P. scapulatus for Hendra virus in Australia (Edson et al., 2015). However, a little knowledge is available about the dynamics of Hendra virus infection and maintenance in bat. The horses probably get Hendra virus infection from flying foxes by spillover (Field et al., 2011). The periodic outbreaks of Hendra virus in local flying fox population lead to an increased incidences of spillover infection to horses. The Hendra virus infection in flying foxes increases when threshold number of susceptible flying foxes is reached and virus enters the flying fox population from a nomadic individual or group. This concept was well studied for related morbilliviruses (Bolker \& Grenfell et al., 1996; Swinton et al., 1998).

Nipah virus was isolated form adult male human and pigs showing symptoms of respiratory illness, fever and encephalitis in Malaysia in 1999 (Chua et al., 1999). The disease was found highly fatal for human patients. Further, investigation showed that most of the human patients were having history of direct pig contact (Chua et al., 2000). Later on, variable flying fox (Pteropus hypomelanus) and large flying fox (P. vampyrus) were found as natural reservoir hosts for Nipah virus (Chua et al., 2002a; Chua et al., 2002b). Nipah virus associated disease was also reported from human in Bangladesh (Sazzad et al., 2013; Chakraborty et al., 2016). Nipah virus outbreak in Bangladesh was very similar to Malaysian outbreak in several aspects such as fever, central nervous system signs, delayed recognition and a high case fatality rate. However, in Bangladesh human cases were not directly associated with disease in pigs, and some evidence of human to human transmission was also reported (Hsu et al., 2004). The serological surveys in Bangladesh suggested that Nipah virus is transmitted by only the Indian flying foxes (Hsu et al., 2004). Nipah virus infections were also reported from human in India (Chadha et al., 2006). Later on, neutralizing antibodies against Nipah virus was also reported from large flying foxes in Cambodia (Olson et al., 2002) and Indonesia (Sendow et al., 2006). Thus, henipaviruses are reported from human and bats in several countries across the globe (Halpin et al., 2000).

The detail molecular genetics study also evidenced that Nipah and Hendra viruses are circulating in their natural hosts, flying foxes since ancient days (Gould, 1996). However, the recent outbreak of Nipah and Hendra virus in human population suggests some major changes in behavior and habitat change in bats. The emergence of flying fox populations under stress 
conditions due to habitat loss altered the foraging and behavioral patterns which results in virus niche expansion and closer proximity to livestock and human population. This may be the pathway of Nipah virus outbreak in human (Chua et al., 2002a).

\subsection{Menangle and Tioman Viruses}

Menangle virus of genus Rubulavirus and family Paramyxoviridae was originally isolated from stillborn piglets near Menangle in Australia in 1997 (Philbey et al., 1998). The affected litters were characterized by mummification, autolyzing, stillborn and live piglets. Several teratogenic defects such as brachygnathia, arthrogryposis and kyphosis were also reported (Barr et al., 2012). It has been proved that Menangle virus has significant tissue tropism for secondary lymphoid organs in pigs and humans and for intestinal epithelium in weaned piglets (Bowden et al., 2012). Serological analysis of persons in contact with the infected pigs also showed the high titers of antibodies against Menangle virus along with clinical signs of febrile illness with measles like rash. However, none of the persons were in direct exposure to flying foxes (Chant et al., 1998). Further study showed that bats living in mixed colonies of little red flying foxes and gray headed flying foxes near the pig farm had neutralizing antibodies against the virus (Philbey et al., 1998). Although the virus isolation from flying foxes were unsuccessful, the paramyxovirus like virion particles labeled with antibody against Menangle virus was reported from flying fox feces collected near the pig farm and a convalescent sow by electron microscopy.

The Tioman virus is a rubulavirus and is distinct from Menangle virus. It is antigenically related to Menangle virus and harboured by Pteropid fruit bats (Yaiw et al., 2008). It was isolated from variable flying foxes in Malaysia. It was discovered accidently during identification of natural host of Nipah virus which caused large scale outbreaks of encephalitis in pigs and humans in Singapore and Malaysia in 1998-1999. It is a newly recognized paramyxovirus and little is known about its pathogenesis and host range (Chua et al., 2001).

\subsection{SARS-CoV like viruses}

An unrecognized corona virus from family Coronaviridae was reported as causative agent of severe acute respiratory syndrome in humans in 2002 (Rota et al., 2003). The virus was later named as severe acute respiratory syndrome-corona virus (SARS-CoV), which is a distant relative of group 2 coronaviruses of rodents, dogs, cattle, pigs, and humans (Gorbalenya et al., 2004). The epidemiologic studies suggested that SARS outbreaks were directly associated with wildlife meat industry. The SARS-CoV like viruses were also isolated from some of the wildlife species such as raccoon dogs (Nyctereutes procyonoides) and masked palm civets (Paguma larvata). The SARS-CoV specific antibodies were also detected in hog badger (Arctonyx collaris) in China (Guan et al., 2003). The viral RNA was detected by reverse
transcription-PCR (RT-PCR) from some of the seronegative animals suggesting acute infection. However, the continuous virus shedding from seropositive animals also suggested the presence of persistent infections in some animals (Guan et al., 2003). Further study also proved the palm civets act as an incidental host for SARS-CoV rather than principal host.

Later on, it was reported that some of the bats (Chinese horseshoe bats; family Rhinolophidae and genus Rhinolophus) possessed either antibody against SARS-CoV or infected with SARS-CoV like viruses ( $\mathrm{Li}$ et al., 2005). The genome sequences of SARS-CoV from humans and civets were also found phylogenetically close to bat SARS-CoV like viruses ( $\mathrm{Li}$ et al., 2005). It suggests the origin of humans and civets SARS-CoV is associated with bat viruses in China. Further study also suggest origin of human SARS-CoV might be from unrecognized SARS-CoV like virus of bat origin which was transmitted to amplifying hosts viz. raccoon dogs, masked palm civets and hog badger and spilling over to human population through close contact with these animals or their tissues. Later on adaptive mutations in virus genome lead to human to human transmission of virus (Song et al., 2005).

The disease potential of a SARS like virus, SHC014-CoV from Chinese horse shoe bat (Rhinolophidae) was studied using reverse genetics system where a chimeric virus was prepared which expressed spikes of bat coronavirus SHC014 in a mouse adapted wild type SARS-CoV backbone (Menachery et al., 2015). In mouse, chimeric virus developed severe pathogenesis which was found untreatable with anti-SARS immunotherapeutics. Moreover, chimeric virus replicated in primary human airway cell line and produced an equivalent titer of SARS-CoV outbreak from human (Ge et al., 2013; Menachery et al., 2015) which indicates a vital threat of reemergence of human SARS-CoV from wild bat population.

\subsection{Middle East respiratory syndrome (MERS)}

MERS causes severe respiratory illness in human. MERS was first time reported from Saudi Arabia in 2012 (Bermingham et al., 2012). Later on, it has been spread to several other countries. Most people suffered with this disease develop symptoms of severe acute respiratory illness such as cough, fever and shortness of breath. MERS is caused by a corona virus called MERS-CoV. For MERS the case-fatality rate is reported as about $45 \%$.It may cause infection to pregnant woman and develop severe respiratory signs (Alserehi et al., 2016). MERS-CoV and SARS-CoV are very similar, which suggests that bats may also play a role in transmission of MERS CoV to human population. The partial RNA sequence of betacoronavirus from faecal pellet of an Egyptian tomb bat Taphozous perforates showed $100 \%$ nucleotide identity with virus isolated from human index case patient (Memish et al., 2013). One of the camel species (Camelus dromedarius) may harbor this virus in nature, because MERS-CoV can be experimentally established in camel (Adney et al., 2014; Raj et al., 2014; Omrani et al., 2015). 
The Filoviridae family of virus consists of genus Ebolavirus (Ebola Sudan virus, Ebola Zaire virus, Ebola Reston virus and Ebola Ivory Coast virus) and Marburgvirus (Marburg virus). The natural reservoirs of these viruses are not yet confirmed. However, the RNA genome of Ebola virus has been identified in terrestrial mammals in Central African Republic (Morvan et al., 1999). Ebola virus may cause highly fatal haemorrhagic disease in human, which may also infect other mammals (Dhama et al., 2015). The high viral loads in body fluids allow virus transmission from human to human (To et al., 2015). A serious Ebola virus outbreak was started in December 2013 in West Africa which also reached to other continents (Gumusova et al., 2015). Experimentally, Ebola Zaire virus was also replicated in little free-tailed bat (Chaerephon pumilus), Angola free tailed bat (Mopscondylurus) and Wahlberg's epauletted fruit bat species (Epomophorus wahlbergi) (Swanepoel et al., 1996). The serological surveillance also showed presence of $\mathrm{IgG}$ immunoglobulin in $4 \%$ of bat population of six species viz. Hypsignathus monstrosus, Epomops franqueti, Myonycteris torquata, Mops condylurus, Micropteropus pusillus and Rousettus aegyptiacus (Pourrut et al., 2009). Later on Ebola virus RNA was also detected in spleen and liver tissues of some fruit bats species viz. Hypsignathus monstrosus, Epomops franqueti and Myonycteris torquata (Leroy et al., 2005). The qPCR assay have successfully detected the Reston ebolavirus (RESTV) specific RNA segments from oropharyngeal swabs of several bat species (Miniopterus schreibersii, M. australis, C. brachyotis and Ch. plicata) from Philippines (Jayme et al., 2015). The detection of Ebola virus RNA from bats is a fascinating finding, but only based on nucleic acid detection it is difficult to establish the bat as reservoir host. It is also suggested that there might be a nonpathogenic undetected Ebola virus spreading in bat population which may give rise to pathogenic strain by mutations in other mammals (Monath, 1999). However, until and unless virus is isolated from bat species, the experimental infections unambiguously demonstrate that virus is persisting as well as transmitting from bat species to other mammals.

\subsection{Marburg virus}

Marburg virus was first reported from an epidemic in Frankfurt and Marburg in Germany and Belgrade in the former Yugoslavia. Marburg virus belongs to Filoviridae family. It causes highly fatal disease in human called Marburg virus disease (MVD). Although it is a rare disease, it may cause high fatality in human during outbreak. The case fatality rate of MDV was reported from $25 \%$ in the initial laboratory based study in 1967, to more than $80 \%$ during outbreaks in Democratic Republic of Congo in 1998-2000 and in Angola in 2005 (http://www.who.int/csr/disease/marburg/en/). This virus is transmitted either by direct contact with the tissues, blood and other body fluids of infected persons or handling dead or ill infected animals such as fruit bats and monkeys. Some of the study in Uganda showed that fruit bat of Rousettus aegyptiacus species might be a natural reservoir for Marburg virus (Amman et al., 2012). The Marburg virus specific IgG and nucleic acid (RNA) was detected in naturally infected individual fruit bat (Rousettus aegyptiacus) in Gabon indicating the Rousettus aegyptiacus as natural reservoir for Marburg virus (Towner et al., 2007). Later on, serological surveillance also revealed the presence of antibody against Marburg virus in $1 \%$ of bat population of Hypsignathus monstrosus and Rousettus aegyptiacus species (Pourrut et al., 2009). The experimental infection of Marburg virus to Rousettus aegyptiacus species of bats also showed the wide distribution of virus in bat tissues followed by recovery of large quantity of viral RNA which suggested the natural reservoir potential of Rousettus aegyptiacus species of bat (Jones et al., 2015; Amman et al., 2015a).

\subsection{Sosuga virus}

Sosuga virus is a novel paramyxovirus which may cause severe acute febrile condition in human. In 2012, a female wildlife biologist reported the malaise, fever, generalized myalgia, headache, arthralgia, neck stiffness and sore throat after a short field expedition for collection of bats and rodents in South Sudan and Uganda (Albarino et al., 2014). However, the patient recovered successfully with adequate medical support. The metagenomics studies of pathogen nucleic acid suggest that the etiological agent might be a novel paramyxovirus related to rubula like viruses of fruit bats origin (Albarino et al., 2014). The new virus was named as Sosuga virus (on name of South Sudan and Uganda). It was also established that virus is most likely originated in bats. However, the efforts to virus detection in African bats are still under way.

To establish the fact regarding bat as potential reservoir, the bat tissues collected during the last three week period prior to onset of clinical symptoms were tested for presence of Sosuga virus (Amman et al., 2015b). It was reported that several Egyptian rousette bats (Rousettus aegyptiacus) were found positive for Sosuga virus. Further analysis of Egyptian rousette bat tissues collected from other locations in Uganda were also found positive for Sosuga virus (Amman et al., 2015b). This suggests that Egyptian rousette bats could be a potential natural reservoir for Sosuga virus.

\section{Routes for transmission of bat-borne viruses to human}

Many of the bat associated viruses are restricted to specific geographical regions with availability of bat reservoir host, such as Egyptian fruit bats associated Ebola virus in Africa and flying foxes associated Hendra and Nipah virus in Australia and Southeast Asia. However, how bat transmit diseases to human is a mystery because most of the bat species remain away from human dwellings in tropical rain forests and in caves. The studies of bat transmitted zoonotic diseases revealed that most probably these diseases are transmitted to humans either via intermediate host or direct contact with bats (Figure 1). Therefore some of the hypotheses for transmission of bat borne disease to human have been proposed. 


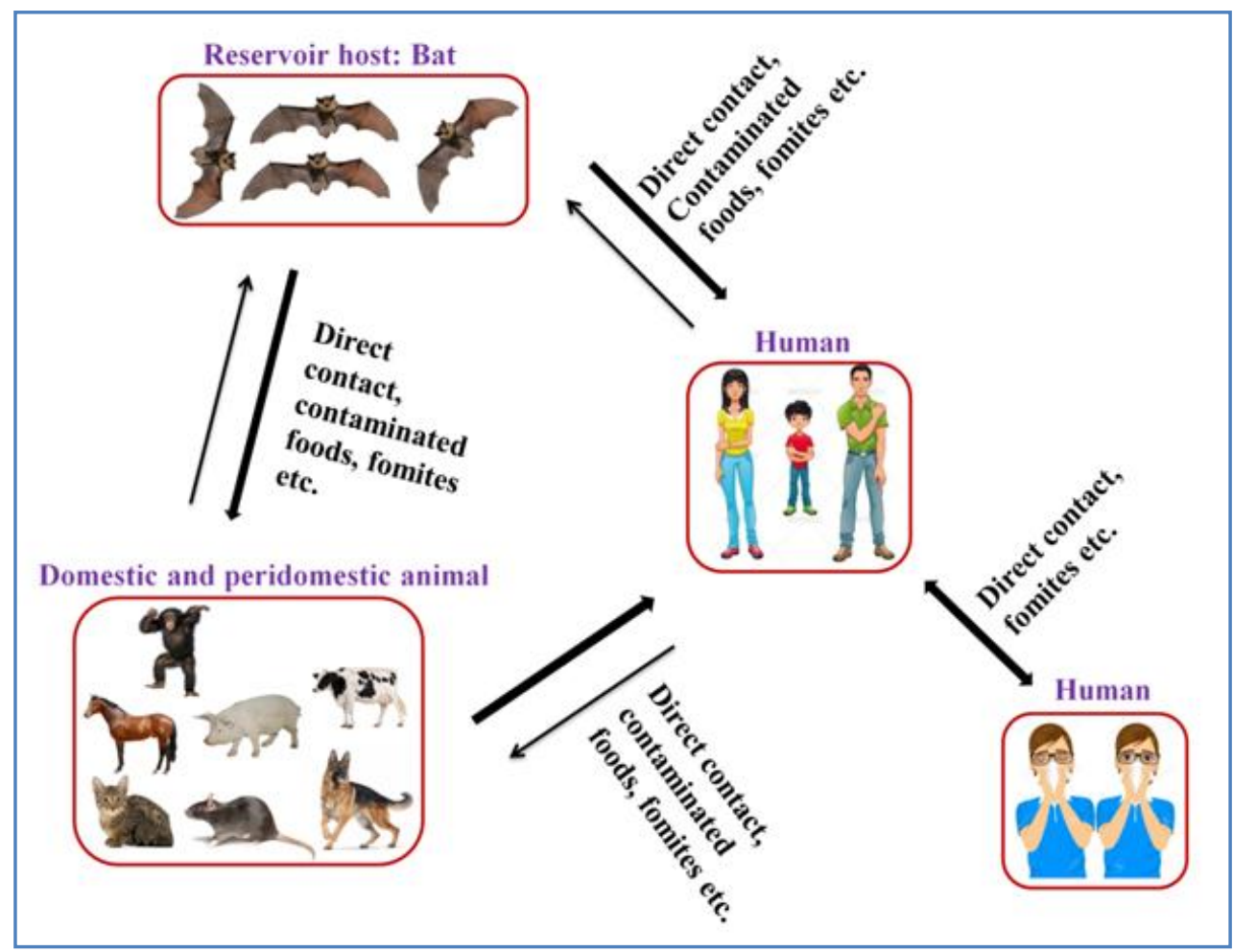

Figure 1 Common routes of transmission of bat associated EIDs between bats, animals and human. Thick arrows represent the most significant pathways whereas thin arrows represent less common or less known pathways for bat-associated EIDs transmission.

\subsection{Transmission through direct contact}

Bats usually reside in dark caves and deep forests. Therefore the direct contact of bat with human is a rare incidence. However, people may get infection of bat associated viruses by bat bite and handling of live bats during capture and consumption of bat meat (Marí Saéz et al., 2015). The capture and selling of wild animals including bats increases the risk of zoonotic virus outbreak in human population (Figure 1). In 2007, Ebola hemorrhagic fever virus outbreak costs life of 186 human in Democratic Republic of Congo (DRC). The epidemiological investigation reported that infection reach to human population by consumption of infected fruit bats meat (Leroy et al., 2009). The transmission by direct contact or ingestion of food infected with bat droppings, is an important source because several viral nucleic acid have been extracted from bat droppings (Halpin et al., 2000; Marí Saéz et al., 2015). Sometimes, accidental bat bite may also result in human rabies. In South Africa human death was reported by Duvenhage virus (DUVV) infection by bat scratch (Adjemian et al., 2011).

\subsection{Transmission through intermediate host}

It is proposed that bats may transmit disease to human through an intermediate host which is close to human and may amplify the virus. The remaining contaminated fruits eaten by fruit bats may be consumed by intermediate hosts such as horses, pigs and non-human primates. Human may get infection from these intermediate hosts by direct contact or consuming their products. In tropical Australia and Southeast Asia, Hendra and Nipah viruses are transmitted by flying foxes. During Nipah virus outbreak in 1998 in Malaysia, it was hypothesized that pigs get infection of Nipah virus by consuming the half consumed mangoes by flying foxes. Mangoes were a major food for flying foxes, and half consumed mangoes contaminated by urine and saliva of bats was accidently consumed by pigs (Figure 1). This results in cross-species infection of pigs followed by subsequent infection to human (Chua et al., 2002a).

Horses may get Hendra virus infection by consuming contaminated fruit, grass, feed or water by bat's saliva, urine and feces and subsequently infection may reach to human (Plowright et al., 2015). Camels play major role in human life in Middle East countries for transportation as well as entertainment. It was hypothesized that dromedary camels act as intermediate host for MERS-CoV infection from bats to humans (Memish et al., 2014). MERS-CoV was also detected in camel milk (Reusken et al., 2014). Thus, virus may be excreted in milk and poses a high risk of infection for people either during milking process or consumption of unpasteurized milk. In 2003, severe SARS outbreak was reported in China. The SARS-CoV was transmitted from bat to palm civet and 
subsequently to human (Liu, 2003). In Central Africa, Ebola virus was transmitted to apes by consumption of fruit contaminated by bats (Leroy et al., 2005).

\subsection{Transmission through aerosol}

Bat may spread large number of viruses in air. Thus, air may get contamination by bat borne viruses especially in caves. People may get infection by bat borne viruses by inhalation of contaminated air (Figure 1). The lethal viral hemorrhagic fever outbreak in Cynomolgus macaques was reported by inhalation of aerosols containing Marburg virus (MARV-Angola) (Alves et al., 2010). Some reports suggest that human may get infection of Marburg virus by visiting in caves in Africa. The most probable route of transmission in this condition might be by aerosol transmission (Timen et al., 2009).

\section{Isolation and characterization of virus}

Viruses from several tissues samples can be grown in a variety of cell culture system in laboratory. For molecular diagnostic study nucleic acid isolation from cell culture material is a good choice. Nucleic acid isolation followed by PCR assays is extremely rapid and sensitive technique. Several other sensitive diagnostic assays such as multiplex PCR, RT-PCR, Real-time PCR etc. are also used for viral emerging infectious diseases (EIDs) diagnosis (Rihtaric et al., 2010; Huang et al., 2012; Freuling et al., 2013; Suin et al., 2014). For identification of a newly recognized virus, PCR amplification of viral nucleic acid followed by nucleic acid sequence data analysis is used. The nucleic acid sequence data of viral pathogens are compared with available sequences in GenBank database (http://www.ncbi.nih.gov/GenBank/) to search for sequence similarities with nucleic acid sequences of known viruses. Moreover, recombinant viral proteins expressed in other expression system can also be used for serodiagnostic tests. During diagnosis of EIDs extra precaution should be taken to avoid misdiagnosis. For example, the first report of Nipah virus infection in Malaysia in 1999 was misdiagnosed as Japanese encephalitis virus (JEV) infection (Calisher et al., 2006). Although, all the human patients were of adult age male already vaccinated against JEV and pigs also suffered a fatal disease, the disease was misdiagnosed as JEV. Later on the failure of intensive vaccination in clinical disease control forced the medical and scientific community to think about new emerging disease. But, by the time there is a huge economic and human life loss was reported. Such incidences force us for certain degree of intellectual preparedness in terms of reagents, equipments and scientific knowledge that could be used for development of rapid diagnostic assays during outbreak of newly emerged viruses.

\section{Diagnostic limitations}

Several diagnostic assays based on serological techniques such as ELISA, immunofluorescence assay etc and molecular techniques viz. PCR, Real-Time PCR, multiplex PCR, nucleic acid sequencing etc are available for sensitive detection of viruses of bat origin. However, for diagnosis of previously unrecognized viruses, new assays and reagents are required. For identification of new viruses PCR will be useful which needs knowledge of nucleic acid sequences of recognized bat associated viruses such as viruses of Mononegavirales order (family Bornaviridae, Filoviridae, Rhabdoviridae, and Paramyxoviridae) for suitable primer designing (Pringle, 1991). In addition, specific antibody conjugates may also be required for enzyme-linked immunosorbent assays or immunofluorescence assays to identify either virus specific antibodies in sera samples or antigens in tissue samples.

Some of the classical methods such as hemagglutination or hemagglutination inhibition tests were also used for viral diagnosis. However, these assays are broadly cross-reactive. Several cell cultures and animal inoculations can also be used for virus isolation. However, for bat associated zoonotic viruses this technique is potentially hazardous, and it should not be used without appropriate biocontainment. With the advancement in molecular biology techniques for viral nucleic identification, virus isolation technique is not much appreciated. However, virus isolation technique will provide us virus in bulk quantity which may be used in many areas of research and development such as development of vaccines, suitable diagnostics and animal disease model to study the pathogenesis of virus.

\section{Bats and emerging viruses}

More than 200 different viruses under 27 families are detected in some species of bats (Moratelli \& Calisher, 2015). However, only few viral diseases such as SARS, MERS, Ebola virus disease etc are transmitted from bats to human (Moratelli \& Calisher, 2015). Because a large proportions of bats under mammalian species (about 20\%), their diverse habitats, biology and natural history, it assumed that bats may harbor several other viruses of human and animal importance (O'Shea et al., 2014; Brook \& Dobson, 2015).

However, the transmission of zoonotic viruses through bat is mostly based up on assumptions. Proper investigation is still required for establishment of role of bat in zoonotic virus transmission (Fenton et al., 2006). In most of the study same viruses are detected both in bats and humans, but this does not prove the bats as reservoir host. Many of the viral nucleic acid sequences have been isolated from bat tissues or excreta. The virus might be entered to bat body through food chain. It only indicates that bats may act as temporary host for those viruses (Calisher et al. 2006; Melaun et al., 2014).

Bats share several immunophysiological parameters to human. This probably occurred due to the fact that bats are in close contact with human population since several years in many parts of the world for habitat and food requirements. Such interaction of bat with human and other animals favors the chance of potential spillover of diseases. Some of the phylogenetically related species of bats may act as intermediate host for bat transmitted viruses. It explains the 
transmission of Hendra and Nipah diseases to human. However, in some of the cases spill over infection is also caused by other animal species such as palm civets, pigs, raccoon dogs and horses. In Malaysia, it was established that Nipah virus was spilled over to human population through pigs from fruit eating bats (Chua et al., 2002b; Dobson, 2006). Some of the insects such as Haematophagous sp. may also transmit virus from bat to human (Melaun et al., 2014). It is also reported that mechanical transmission of bat associated zoonotic viruses to human population is also possible.

\section{Control and prevention of bat-associated emerging infectious diseases (EIDs)}

Several factors progressing from primary to more proximate drive disease emergence from bats. For bat originated viral disease control such factors should be taken in consideration. Several steps should be taken for control of bat transmitted zoonotic viruses. Such steps should be initiated at individual level, population level and at societal level.

\subsection{Individual level control}

In most of the cases no specific medical therapy has been found beneficial in bat associated viral EID. In human rabies therapeutic measures are very challenging and in most of the cases they fail to save the patient life. The early diagnosis i.e. before onset of fulminant stage in animal may allow effective prophylaxis in human. The prognoses of fulminant rabies carry a very poor and unfavorable result. In medical history the first case of successful experimental rabies treatment (Milwaukee Protocol) was reported in a 15 year old girl bitten by a bat in 2004 (Willoughby et al., 2005). Later on, extension of Milwaukee Protocol (consisting of antiviral drugs therapy, therapeutic coma and intensive medical care) did not show much successful in many other patients (Rupprecht, 2009; Rubin et al., 2009). The suitable prophylaxis measures before the onset of illness, has proved a much higher success rate in several other bat associated EIDs. For treatment of viral diseases modern molecular biology approach may also be used. The currently untreatable infection of henipaviruses may be treated with small interfering RNA (siRNA) molecules homologous to viral RNA (Mungall et al., 2008). Although, siRNA has capability to treat several viral infections, it is still under developmental phase. Several issues related to siRNA such as its delivery, efficacy in humans and cost effectiveness has yet to address.

Moreover, the possibility of potential use of Ebola virus as bioweapons has forced scientific community for development of an effective vaccine product for any emergency outbreak. In mouse model of hemorrhagic Ebola virus infection, the vesicular stomatitis virus based recombinant vaccine has proved its safety and efficacy in preventing clinical signs of disease (Jones et al., 2007). Ebola virus vaccines can also be delivered through mucosal surface route. This vaccine delivery approach is very rapid and may prove advantageous during sudden disease outbreak.
8.2 Population level control

The bat associated viral EIDs should be addressed intensively at population level. The population level study of several bats associated EIDs have been carried out. Rabies is studied in depth and public health guidelines including vaccination of pets and other animals on public display, vaccination of humans in high risk groups, separation of domestic and pet animals from the wildlife reservoirs of rabies, public awareness regarding rabies etc was issued for rabies control. The current recommendation also advocates about pre and post exposure prophylaxis for high risk group individuals such as animal handlers, veterinarians, rabies researchers and laboratory workers and long term travelers to rabies endemic areas (NASPHV, 2009). Despite advances in epidemiology, molecular biology and vaccination science the proper control of bat associated viral EIDs remains challenging in many parts of the world. To reduce the bat associated viral EIDs outbreaks in human population, measure should be taken to control either the bat population or viral infection to bat population. In one of such measure anticoagulant on vampire bats can be applied and subsequently bats should release in wild condition (Kuzmin \& Rupprecht, 2007). This will lead to consumption of anticoagulant by other vampire bats during grooming. It is well established that vampire bats can digest only coagulated blood. Thus, they may die by blood feeding which will remain uncoagulated in their digestive system. The anticoagulant can also be applied on animal skin to control bat population (Kuzmin \& Rupprecht, 2007).

\subsection{Societal level control}

The recent global emergence of Henipavirus and SARS coronavirus of Bat origin has started a new discussion on how to control disease emergence. The possible reasons of emergence of bat associated viral EIDs are environmental changes, increased human mobility and overpopulation. Therefore, to control viral EIDs monitoring of increased global mobility with other practical measures such as surveillance of transportation can be initiated. The intensive monitoring of borders and ports can be initiated for ill passengers and animals. Proper care and management facility should be provided which will benefit the ill animal and human as well as population moving from there. Moreover, for international travelers specific health measures such as pre-travel vaccination as well as post-travel health checkup should be initiated.

Environmental conservation is also essential for sustenance of biodiversity and natural habitat. It is reported that many of the wild animals including bats are now reaching to human dwellings for food and shelter which also carry the EIDs to human population. The evidence show that environmental degradation play a major role in increased rates of disease emergence especially EIDs. However, the exact role of loss of environmental conservation in EIDs is still not understood, therefore further study is needed to establish the facts. 


\section{Conclusion and future perspective}

Bats cover the diverse group of mammalian species. They harbor several zoonotic viruses in their body than any other animal species (Hayman et al., 2013; Luis et al., 2013). It explains the necessity of knowledge of immune resistance mechanisms of bat that allow bats to harbor viral pathogens, mechanisms underlying disease emergence and pathogenic basis of viral diseases in bats (Dobson, 2006; Daszak et al. 2013; Mandl et al. 2015). To address such issues field epidemiological studies along with intensive laboratory experiments on bat associated virus using live bats and bat cell cultures are required. The bat cell lines from bats of different species need to establish to facilitate the in vivo and in vitro experiments.

There is always a threat of experimental introduction and release of virus through laboratory animals, especially laboratory animals of foreign origin in new geographical area. Therefore, to reduce such risks only native laboratory animals should be used for animal experimentations for viruses. These animals should be kept for captive breeding. After few generations of captive breeding physiologically uniform animal strains could be obtained, that can be used in study of zoonotic diseases (Eger \& Gardner, 2008).

It is also necessary to design field studies for continuous search regarding new viral pathogen circulation in bats, their zoonotic potential, role of various abiotic and biotic factors affecting bat populations and their role in disease spillovers to humans (Parrish et al., 2008, Daszak et al., 2013, Marí Saéz et al., 2015). For adequate control of bat associated EIDs epidemiologists as well as wildlife experts should work together to minimize the risk of viral outbreak in human population. The joint expertise of bat biologists, veterinary and medical professionals and molecular biologists can be utilized for control and prevention of bat associated zoonotic viruses. After all, it is difficult to say that bats are responsible for emergence of zoonotic viruses. Only the intensive laboratory research using epidemiological and ecological approaches conducted by molecular biologists, bat biologists, veterinary and medical researchers may provide useful and satisfactory evidence regarding zoonotic virus transmission from bat. The accurate statement will be based on concrete laboratory evidence only.

\section{Conflict of interest}

Authors would hereby like to declare that there is no conflict of interests that could possibly arise.

\section{Acknowledgements}

Authors are thankful to Sardar Vallabhbhai Patel, University of Agriculture and Technology, Meerut, Uttar Pradesh, India for providing facility to prepare the manuscript.

\section{References}

Adjemian J, Farnon EC, Tschioko F, Wamala JF, Byaruhanga E, Bwire GS, Kansiime E, Kagirita A, Ahimbisibwe S, Katunguka F, Jeffs B, Lutwama JJ, Downing R, Tappero JW, Formenty P, Amman B, Manning C, Towner J, Nichol ST, Rollin PE (2011) Outbreak of Marburg hemorrhagic fever among miners in Kamwenge and Ibanda Districts, Uganda, 2007. The Journal of Infectious Diseases 204 (Suppl. 3): S796-S799. doi: 10.1093/infdis/jir312.

Adney DR, van Doremalen N, Brown VR, Bushmaker T, Scott D, de Wit E, Bowen RA, Munster VJ (2014) Replication and shedding of MERS-CoV in upper respiratory tract of inoculated dromedary camels. Emerging Infectious Diseases 20 :1999-2005. doi: 10.3201/eid2012.141280.

Albarino CG, Foltzer M, Towner JS, Rowe LA, Campbell S, Jaramillo CM, Bird BH, Reeder DM, Vodzak ME, Rota P, Metcalfe MG, Spiropoulou CF, Knust B, Vincent JP, Frace MA, Nichol ST, Rollin PE, Ströher U (2014) Novel paramyxovirus associated with severe acute febrile disease, South Sudan and Uganda, 2012. Emerging Infectious Diseases 20: 211-216. doi: 10.3201/eid2002.131620.

Alserehi H, Wali G, Alshukairi A, Alraddadi B (2016) Impact of Middle East Respiratory Syndrome coronavirus (MERS$\mathrm{CoV}$ ) on pregnancy and perinatal outcome. BMC Infectious Diseases 16 :105. doi: 10.1186/s12879-016-1437-y.

Alves DA, Glynn AR, Steele KE, Lackemeyer MG, Garza NL, Buck JG, Mech C, Reed DS (2010) Aerosol exposure to the angola strain of marburg virus causes lethal viral hemorrhagic fever in cynomolgus macaques. Veterinary Pathology $47: 831$ 851. doi: $10.1177 / 0300985810378597$.

Amman BR, Albariño CG, Bird BH, Nyakarahuka L, Sealy TK, Balinandi S, Schuh AJ, Campbell SM, Ströher U, Jones ME, Vodzack ME, Reeder DM, Kaboyo W, Nichol ST, Towner JS (2015b) A Recently Discovered Pathogenic Paramyxovirus, Sosuga Virus, is Present in Rousettus aegyptiacus Fruit Bats at Multiple Locations in Uganda. Journal of Wildlife Diseases 51:774-779. doi: 10.7589/201502-044.

Amman BR, Carroll SA, Reed ZD, Sealy TK, Balinandi S, Swanepoel R, Kemp A, Erickson BR, Comer JA, Campbell S, Cannon DL, Khristova ML, Atimnedi P, Paddock CD, Crockett RJ, Flietstra TD, Warfield KL, Unfer R, KatongoleMbidde E, Downing R, Tappero JW, Zaki SR, Rollin PE, Ksiazek TG, Nichol ST, Towner JS (2012) Seasonal pulses of Marburg virus circulation in juvenile Rousettus aegyptiacus bats coincide with periods of increased risk of human infection. PLOS Pathogens 8 :e1002877. doi: 10.1371/journal.ppat.1002877. 
Amman BR, Jones ME, Sealy TK, Uebelhoer LS, Schuh AJ, Bird BH, Coleman-McCray JD, Martin BE, Nichol ST, Towner JS (2015a) Oral shedding of Marburg virus in experimentally infected Egyptian fruit bats (Rousettus aegyptiacus). Journal of Wildlife Diseases 51:113-124. doi: 10.7589/2014-08-198.

Anderson A, Shwiff S, Gebhardt K, Ramírez AJ, Shwiff S, Kohler D, Lecuona L (2014) Economic evaluation of vampire bat (Desmodus rotundus) rabies prevention in Mexico. Transboundary and Emerging Diseases 61:140-146. doi: 10.1111/tbed.12007.

Barr JA, Smith C, Marsh GA, Field H, Wang LF (2012) Evidence of bat origin for Menangle virus, a zoonotic paramyxovirus first isolated from diseased pigs. Journal of General Virology 93(Pt 12):2590-2594. doi: 10.1099/vir.0.045385-0.

Bermingham A, Chand MA, Brown CS, Aarons E, Tong C, Langrish C, Hoschler K, Brown K, Galiano M, Myers R, Pebody RG, Green HK, Boddington NL, Gopal R, Price N, Newsholme W, Drosten C, Fouchier RA, Zambon M (2012) Severe respiratory illness caused by a novel coronavirus, in a patient transferred to the United Kingdom from the Middle East, September 2012. Eurosurveillance 17:20290.

Bolker BM, Grenfell BT (1996) Impact of vaccination on the spatial correlation and persistence of measles dynamics. Proceedings of National Academy of Science USA 93:1264812653.

Botvinkin AD, Poleschuk EM, Kuzmin IV, Borisova TI, Gazaryan SV, Yager P, Rupprecht CE (2003) Novel lyssavirus isolated from bats in Russia. Emerging Infectious Diseases 9:1623-1625.

Botvinkin AD, Selnikova OP, Antonova LA, Moiseeva AB, Nesterenko EY (2006) Human rabies case caused from a bat bite in the Ukraine. Rabies Bulletin in Europe. 29:5-7.

Bowden TR, Bingham J, Harper JA, Boyle DB (2012) Menangle virus, a pteropid bat paramyxovirus infectious for pigs and humans, exhibits tropism for secondary lymphoid organs and intestinal epithelium in weaned pigs. Journal of General Virology 93(Pt 5):1007-1016. doi: 10.1099/vir.0.038448-0.

Brook CE, Dobson AP (2015) Bats as 'special' reservoirs for emerging zoonotic pathogens. Trends in Microbiology 23:172180. doi: 10.1016/j.tim.2014.12.004.

Calisher CH, Childs JE, Field HE, Holmes KV, Schountz T (2006) Bats: Important reservoir hosts of emerging viruses. Clinical Microbiology Reviews 19:531-545.

Chadha MS, Comer JA, Lowe L, Rota PA, Rollin PE, Bellini WJ, Ksiazek TG, Mishra AC (2006) Nipah virus-associated encephalitis outbreak, Siliguri, India. Emerging Infectious Diseases 12:235-240.

Chakraborty A, Sazzad HM, Hossain MJ, Islam MS, Parveen S, Husain M, Banu SS, PodderG, Afroj S, Rolin PE, Daszak P, Luby SP, Rahman M, Gurley ES (2016) Evolving epidemiology of Nipah virus infection in Bangladesh: evidence from outbreak during 2010-2011. Epidemiology and Infection 155: 371-380. doi: 10.1017/S0950268815001314.

Chant K, Chan R, Smith M, Dwyer DE, Kirkland PE (1998) Probable human infection with a newly described virus in the family Paramyxoviridae. Emerging Infectious Diseases 4:273275.

Chua KB, Bellini W, Rota P, Harcourt B, Tamin A, Lam S, Ksiazek T, Rollin P, Zaki S, Shieh WJ, Goldsmith C, Gubler D, Roehrig J, Eaton B, Gould A, Olson J, Field H, Daniels P, Ling A, Peters C, Anderson L, Mahy B (2000) Nipah virus: a recently emergent deadly paramyxovirus. Science 288:14321435.

Chua KB, Chua BH, Wang CW (2002a) Anthropogenic deforestation, El Nino and the emergence of Nipah virus in Malaysia. The Malaysian journal of pathology 24:15-21.

Chua KB, Goh KJ, Wong KT, Kamarulzaman A, Tan PS, Ksiazek TG, Zaki SR, Paul G, Lam SK, Tan CT (1999) Fatal encephalitis due to Nipah virus among pig-farmers in Malaysia. Lancet 354:1257-1259.

Chua KB, Koh C, Hooi P, Wee K, Khong J, Chua B, Chan Y, Lim M, Lam S (2002b) Isolation of Nipah virus from Malaysian Island flying foxes. Microbes and Infection 4:145151.

Chua KB, Wang LF, Lam SK, Crameri G, Yu M, Wise T, Boyle D, Hyatt AD, Eaton BT (2001) Tioman virus, a novel paramyxovirus isolated from fruit bats in Malaysia. Virology 283:215-229.

Dacheux L, Larrous F, Mailles A, Boisseleau D, Delmas O, Biron C, Bouchier C, Capek I, Muller M, Ilari F, Lefranc T, Raffi F, Goudal M, Bourhy H (2009) European bat lyssavirus transmission among cats, Europe. Emerging Infectious Diseases 15:280-284.

Daszak P, Zambrana-Torrelio C, Bogich TL, Fernandez M, Epstein JH, Murray KA, Hamilton H (2013) Interdisciplinary approaches to understanding disease emergence: the past, present, and future drivers of Nipah virus emergence. Proceedings of National Academy of Sciences USA 110 Suppl 1:3681-1368. doi: 10.1073/pnas.1201243109.

Dhama K, Karthik K, Chakraborty S, Tiwari R, Kapoor S (2013). Wildlife: a hidden warehouse of zoonosis - a review. International Journal of Current Research 5: 1866-1879. 
Dhama K, Malik YS, Malik SV, Singh R K (2015). Ebola from emergence to epidemic: the virus and the disease, global preparedness and perspectives. Journal of Infection in Developing Countries 9 :441-455. doi: 10.3855/jidc.6197.

Dobson AP (2006) Response to: linking bats to emerging diseases. Science 1999:311.

Drexler JF, Corman VM, Müller MA, Maganga GD, Vallo P, Binger T, Gloza-Rausch F, Cottontail VM, Rasche A, Yordanov S, Seebens A, Knörnschild M, Oppong S, Adu Sarkodie Y, Pongombo C, Lukashev AN, Schmidt-Chanasit J, Stöcker A, Carneiro AJ, Erbar S, Maisner A, Fronhoffs F, Buettner R, Kalko EK, Kruppa T, Franke CR, Kallies R, Yandoko ER, Herrler G, Reusken C, Hassanin A, Krüger DH, Matthee S, Ulrich RG, Leroy EM, Drosten C (2012). Bats host major mammalian paramyxoviruses. Nature Communications 3:796. doi: 10.1038/ncomms1796.

Edson D, Field H, McMichael L, Vidgen M, Goldspink L, Broos A, Melville D, Kristoffersen J, de Jong C, McLaughlin A, Davis R, Kung N, Jordan D, Kirkland P, Smith C (2015) Routes of Hendra virus excretion in naturally-infected flyingfoxes: implications for viral transmission and spillover risk. PLoSOne 10 :e0140670. doi: 10.1371/journal.pone.0140670.

Eger JL, Gardner AL (2008) Mammals of South America. Vol. 1. University of Chicago Press; Chicago, Genus Cynomops O Thomas, 1920; pp. 402-407. (Marsupials, xenarthrans, shrews and bats).

Fenton MB, Davison M, Kunz TH, McCracken GF, Racey PA, Tuttle MD (2006) Linking bats to emerging diseases. Science 311:1998-1999.

Field H, de Jong C, Melville D, Smith C, Smith I, Broos A, Kung YH, McLaughlin A, Zeddeman A (2011) Hendra virus infection dynamics in Australian fruit bats. PLoSOne 6 :e28678. doi: 10.1371/journal.pone.0028678.

Fraser GC, Hooper PT, Lunt RA, Gould AR, Gleeson LJ, Hayatt AD, Russell GM, Kattenbelt JA. (1996) Encephalitis caused by a lyssavirus in fruit bats in Australia. Emerging Infectious Diseases 2:327-331.

Freuling CM, Abendroth B, Beer M, Fischer M, Hanke D, Hoffmann B, Höper D, Just F, Mettenleiter TC, Schatz J, Müller T (2013) Molecular diagnostics for the detection of Bokeloh bat lyssavirus in a bat from Bavaria, Germany. Virus Research 177 :201-204. doi: 10.1016/j.virusres.2013.07.021

Ge XY, Li JL, Yang XL, Chmura AA, Zhu G, Epstein JH, Mazet JK, Hu B, Zhang W, Peng C, Zhang YJ, Luo CM, Tan B, Wang N, Zhu Y, Crameri G, Zhang SY, Wang LF, Daszak P, Shi ZL (2013) Isolation and characterization of a bat SARSlike coronavirus that uses the ACE2 receptor. Nature 503 :535538. doi: 10.1038/nature12711.
Gilbert AT, McCracken GF, Sheeler LL, Muller LI, O'Rourke D, Kelch WJ, New JC Jr (2015) Rabies surveillance among bats in Tennessee, USA, 1996-2010. Journal of Wildlife Diseases 51:821-832. doi: 10.7589/2014-12-277

Gorbalenya AE, Snijder EJ, Spaan WJ (2004) Severe acute respiratory syndrome coronavirus phylogeny: toward consensus. Journal of Virolology 78:7863-7866.

Gould AR (1996) Comparison of the deduced matrix and fusion protein sequences of equine morbillivirus with cognate genes of the Paramyxoviridae. Virus Research 43:17-31.

Gould AR, Kattenbelt JA, Gumley SG, Lunt RA (2002) Characterisation of an Australian bat lyssavirus variant isolated from an insectivorous bat. Virus Research 89:1-28.

Guan Y, Zheng BJ, He YQ, Liu XL, Zhuang ZX, Cheung CL, Luo SW, Li PH, Zhang LJ, Guan YJ, Butt KM, Wong KL, Chan KW, Lim W, Shortridge KF, Yuen KY, Peiris JS, Poon LL (2003) Isolation and characterization of viruses related to SARS coronavirus from animals in southern China. Science 302:276-278.

Gumusova S, Sunbul M, Leblebicioglu H (2015) Ebola virus disease and the veterinary perspective. Annals of Clinical Microbiology and Antimicrobials 14:30. doi: 10.1186/s12941015-0089-x.

Halpin K, Young PL, Field HE, Mackenzie JS (2000) Isolation of Hendra virus from pteropid bats: a natural reservoir of Hendra virus. Journal of General Virology 81:1927-1932.

Hanlon CA, Kuzmin IV, Blanton JD, Weldon WC, Manangan JS, Rupprecht CE (2005) Efficacy of rabies biologics against new lyssaviruses from Eurasia. Virus Research 111:44-54.

Hayman DT, Bowen RA, Cryan PM, McCracken GF, O'Shea TJ, Peel AJ, Gilbert A, Webb CT, Wood JL (2013) Ecology of zoonotic infectious diseases in bats: current knowledge and future directions. Zoonoses and Public Health 60 :2-21. doi: 10.1111/zph.12000.

Hill JE, Smith JD (1984) Bats: a natural history. University of Texas Press, Austin.

Hsu VP, Hossain MJ, Parashar UD, Ali MM, Ksiazek TG, Kuzmin I, Niezgoda M, Rupprecht C, Bresee J, Breiman RF (2004) Nipah virus encephalitis reemergence, Bangladesh. Emerging Infectious Diseases 10:2082-2087.

Huang Y, Wei H, Wang Y, Shi Z, Raoul H, Yuan Z (2012) Rapid detection of filoviruses by real-time TaqMan polymerase chain reaction assays. Virologica Sinica 27 :273277. doi: 10.1007/s12250-012-3252-y. 
Hughes GJ, Orciari LA, Rupprecht CE (2005) Evolutionary timescale of rabies virus adaptation to North American bats inferred from the substitution rate of the nucleoprotein gene. Journal of General Virology 86:1467-1474.

Jayme SI, Field HE3, de Jong C, Olival KJ, Marsh G, Tagtag AM, Hughes T, Bucad AC, Barr J, Azul RR, Retes LM, Foord A, Yu M, Cruz MS, Santos IJ, Lim TM, Benigno CC, Epstein JH, Wang LF, Daszak P, Newman SH (2015) Molecular evidence of Ebola Reston virus infection in Philippine bats. Virology Journal 12:107. doi: 10.1186/s12985-015-0331-3.

Jones KE, Patel NG, Levy MA, Storeygard A, Balk D, Gittleman JL, Daszak P (2008) Global trends in emerging infectious diseases. Nature 451:990-993. doi: 10.1038 /nature06536.

Jones ME, Schuh AJ, Amman BR, Sealy TK, Zaki SR, Nichol ST, Towner JS (2015) Experimental Inoculation of Egyptian Rousette Bats (Rousettus aegyptiacus) with Viruses of the Ebolavirus and Marburgvirus Genera. Viruses 7 :3420-3442. doi: $10.3390 / \mathrm{v} 7072779$.

Jones SM, Stroher U, Fernando L, Qiu X, Alimonti J, Melito P, Bray M, Klenk HD, Feldmann H (2007) Assessment of a vesicular stomatitis virus-based vaccine by use of the mouse model of Ebola virus hemorrhagic fever. The Journal of Infectious Diseases 196 Suppl 2:S404-412.

Knobel, DL, Cleaveland S, Coleman PG, Fevre EM, Meltzer MI, Miranda ME, Shaw A, Zinsstag J, Meslin FX (2005) Reevaluating the burden of rabies in Africa and Asia. Bulletin of the World Health Organization 83:360-368.

Koraka P, Martina BE, Roose JM, van Thiel PP, van Amerongen G, Kuiken T, Osterhaus AD (2012) In vitro and in vivo isolation and characterization of Duvenhage virus. PLoS Pathogen 8 :e1002682. doi: 10.1371/journal.ppat.1002682.

Kunz TH, Fenton MB (2003) Bat ecology. University of Chicago Press, Chicago, Illinois ISBN 0-226-46206-4.

Kuzmin IV, Bozick B, Guagliardo SA, Kunkel R, Shak JR, Tong S, Rupprecht CE (2011) Bats, emerging infectious diseases, and the rabies paradigm revisited. Emerging Health Threats Journal 4:7159. doi: 10.3402/ehtj.v4i0.7159.

Kuzmin IV, Franka R, Rupprecht CE (2008) Experimental infection of big brown bats (Eptesicus fuscus) with West Caucasian bat virus (WCBV). Development in Biologicals (Basel) 131:327-337.

Kuzmin IV, Mayer AE, Niezgoda M, Markotter W, Agwanda B, Breiman RF, Rupprecht CE (2010) Shimoni bat virus, a new representative of the Lyssavirus genus. Virus Research 149:197-210. doi: 10.1016/j.virusres.2010.01.018
Kuzmin IV, Rupprecht CE (2007) Bat rabies. In: Jackson AC, Wunner WH, editors. Rabies. 2nd ed. London: Academic Press/Elsevier, pp. 259-307.

Lau SK, Woo PC, Li KS, Huang Y, Tsoi HW, Wong BH, Wong SS, Leung SY, Chan KH, Yuen KY (2005) Severe acute respiratory syndrome coronavirus-like virus in Chinese horseshoe bats. Proceedings of National Academy of Sciences USA 102:14040-14045.

Leonova GN, Belikov SI, Kondratov IG, Krylova NV, Pavlenko EV, Romanova EV, Chentsova IV, Petukhova SA (2010) A fatal case of bat lyssavirus infection in Primorye Territory of the Russian Far East. Rabies Bulletin of Europe 33 :5-8.

Leroy EM, Epelboin A, Mondonge V, Pourrut X, Gonzalez JP, Muyembe-Tamfum JJ, Formenty P (2009) Human Ebola outbreak resulting from direct exposure to fruit bats in Luebo, Democratic Republic of Congo, 2007. Vector Borne Zoonotic Diseases 9 : 723-728. doi: 10.1089/vbz.2008.0167.

Leroy EM, Kumulungui B, Pourrut X, Rouquet P, Hassanin A, Yaba P, Delicat A, Paweska JT, Gonzalez JP, Swanepoel R (2005) Fruit bats as reservoirs of Ebola virus. Nature 438:575576.

Li W, Shi Z, Yu M, Ren W, Smith C, Epstein JH, Wang H, Crameri G, Hu Z, Zhang H, Zhang J, MacEachern J, Field H, Daszak P, Eaton BT, Zhang S, Wang LF (2005) Bats are natural reservoirs of SARS-like coronaviruses. Science 310:676-679.

Liu J (2003) SARS, wildlife, and human health. Science 302 (5642): 53.

Liu Y, Chen Q, Zhang F, Zhang S, Li N, Lian H, Wang Y, Zhang J, Hu R (2013b) Evaluation of rabies biologics against Irkut virus isolated in China. Journal of Clinical Microbiology 51:3499-3504. doi: 10.1128/JCM.01565-13.

Liu Y, Zhang S, Zhao J, Zhang F, Hu R (2013a) Isolation of Irkut virus from a Murina leucogaster bat in China. PLoS Neglected Tropical Diseases 7 :e2097. doi: 10.1371/journal.pntd.0002097.

López-Roig M, Bourhy H, Lavenir R, Serra-Cobo J (2014) Seroprevalence dynamics of European bat lyssavirus type 1 in a multispecies bat colony. Viruses 6 :3386-3399. doi: 10.3390/v6093386.

Luis AD, Hayman DT, O'Shea TJ, Cryan PM, Gilbert AT, Pulliam JR, Mills JN, Timonin ME, Willis CK, Cunningham AA, Fooks AR, Rupprecht CE, Wood JL, Webb CT (2013) A comparison of bats and rodents as reservoirs of zoonotic viruses: are bats special? Proceedings Biological Sciences 280:1-9. doi: 10.1098/rspb.2012.2753. 
Mandl JN, Ahmed R, Barreiro LB, Daszak P, Epstein JH, Virgin HW, Feinberg MB (2015) Reservoir host immune responses to emerging zoonotic viruses. Cell 160:20-35. doi: 10.1016/j.cell.2014.12.003.

Marí Saéz A, Weiss S, Nowak K, Lapeyre V, Zimmermann F, Düx A, Kühl HS, Kaba M, Regnaut S, Merkel K, Sachse A, Thiesen U, Villányi L, Boesch C, Dabrowski PW, Radonić A, Nitsche A, Leendertz SA, Petterson S, Becker S, Krähling V, Couacy-Hymann E, Akoua-Koffi C, Weber N, Schaade L, Fahr J, Borchert M, Gogarten JF, Calvignac-Spencer S, Leendertz FH (2014) Investigating the zoonotic origin of the West African Ebola epidemic. EMBO Molecular Medicine 7 :17-23. doi: 10.15252/emmm.201404792.

Markotter W, Kuzmin IV, Rupprecht CE, Nel LH (2009) Lagos bat virus virulence in mice inoculated by the peripheral route. Epidemiology and Infection 137:1155-1162. doi: $10.1017 /$ S0950268808001945.

Markotter W, Van Eeden C, Kuzmin IV, Rupprecht CE, Paweska JT, Swanepoel R, Fooks AR, Sabeta CT, Cliquet F, Nel LH (2008) Epidemiology and pathogenicity of African bat lyssaviruses. Development in Biologicals (Basel) 131:317-325.

Marston DA, Vázquez-Morón S, Ellis RJ, Wise EL, McElhinney LM, de Lamballerie X, Fooks AR, Echevarría JE (2015) Complete Genomic Sequence of European Bat Lyssavirus 1, Isolated from Eptesicus isabellinus in Spain. Genome Announcements 3 : e01518-14. doi: 10.1128/genomeA.01518-14.

Maudlin I, Eisler MC, Welburn SC (2009) Neglected and endemic zoonoses. Philosophical Transactions of the Royal Society of London Series B Biological Sciences 364:27772787. doi: 10.1098/rstb.2009.0067.

McMurray DN, Stroud J, Murphy JJ, Carlomagno MA, Greer DL (1982) Role of immunoglobulin classes in experimental histoplasmosis in bats. Developmental and Comparative Immunology 6:557-567.

Melaun C, Werblow A, Busch MW, Klimpel S. Klimpel S, Mehlhorn H (2014) Bats (Chiroptera) as vectors of diseases and parasites. Springer-Verlag; Heidelbergh, Bats as potential reservoir hosts for vector-borne diseases Pp. 25-61. (Parasitology Research Monographs 5).

Memish ZA, Cotten M, Meyer B, Watson SJ, Alsahafi AJ, Al Rabeeah AA, Corman VM, Sieberg A, Makhdoom HQ, Assiri A, Al Masri M, Aldabbagh S, Bosch BJ, Beer M, Muller MA, Kellam P, Drosten C (2014) Human infection with MERS coronavirus after exposure to infected camels, Saudi Arabia, 2013. Emerging Infectious Diseases 20 : 1012-1015. doi: 10.3201/eid2006.140402.

Memish ZA, Mishra N, Olival KJ, Fagbo SF, Kapoor V (2013) Middle East respiratory syndrome coronavirus in bats, Saudi
Arabia. Emerging Infectious Diseases 19:7-13. doi: 10.3201/eid1911.131172.

Menachery VD, Yount BL Jr, Debbink K, Agnihothram S, Gralinski LE, Plante JA, Graham RL, Scobey T, Ge XY, Donaldson EF, Randell SH, Lanzavecchia A, Marasco WA, Shi ZL, Baric RS (2015) A SARS-like cluster of circulating bat coronaviruses shows potential for human emergence. Nature Medicine 21 :1508-1513. doi: 10.1038/nm.3985.

Messenger SL, Smith JS, Orciari LA, Yager PA, Rupprecht CE (2003) Bats, emerging virus infections, and the rabies paradigm. In: Kunz TH, Fenton MB (Eds.) Bat Ecology. Chicago: University of Chicago Press, pp. 622-679.

Monath TP (1999) Ecology of Marburg and Ebola viruses: speculation and directions for future research. The Journal of Infectious Diseases 179(Suppl.):S127-S138.

Moratelli R, Calisher CH (2015) Bats and zoonotic viruses: can we confidently link bats with emerging deadly viruses? Memorias do Instituto Oswaldo Cruz 110 :1-22. doi: 10.1590/0074-02760150048.

Morvan JM, Deubel V, Gounon P, Nakoune E, Barriere P, Murri S, Perpete O, Selekon B, Coudrier D, Gautier-Hion A, Colyn M, Volehkov V (1999) Identification of Ebola virus sequences present as RNA or DNA in organs of terrestrial small mammals of the Central African Republic. Microbes and Infection 1:1193-1201.

Mungall BA, Schopman NC, Lambeth LS, Doran TJ (2008) Inhibition of Henipavirus infection by RNA interference. Antiviral Research 80 : 324-331. doi: 10.1016/j.antiviral.2008.07.004.

Murray K, Selleck P, Hooper P, Hyatt A, Gould A, Gleeson L, Westbury H, Hiley L, Selvey L, Rodwell B, Ketterer P (1995) A morbillivirus that caused fatal disease in horses and humans. Science 268:94-97.

NASPHV (2009) Compendium of measures to prevent disease associated with animals in public settings, 2009: National Association of State Public Health Veterinarians, Inc. (NASPHV). Centers for Disease Control and Prevention; Council of State and Territorial Epidemiologists; American Veterinary Medical Association. MMWR Recomm Rep 58(RR-5):1-21.

Olson J, Rupprecht C, Rollin P, An U, Niezgoda M, Clemins T, Walston J, Ksiazek T (2002) Antibodies to Nipah-like virus in bats (Pteropus lylei), Cambodia. Emerging Infectious Diseases 8:987-988.

Omrani AS, Al-Tawfiq JA, Memish ZA (2015) Middle East respiratory syndrome coronavirus (MERS-CoV): animal to human interaction. Pathogens and Global Health 109 : 354-62. doi: 10.1080/20477724.2015.1122852. 
O'Shea TJ, Cryan PM, Cunningham AA, Fooks AR, Hayman DT, Luis AD, Peel AJ, Plowright RK, Wood JL (2014) Bat flight and zoonotic viruses. Emerging Infectious Diseases 20 : 741-745. doi: 10.3201/eid2005.130539.

Parrish CR, Holmes EC, Morens DM, Park E-C, Burke DS, Calisher CH, Laughlin CA, Saif LJ, Daszak P (2008) Crossspecies viral transmission and the emergence of new epidemic diseases. Microbiology and Molecular Biology Review 72:457-470. doi: 10.1128/MMBR.00004-08.

Peterson AT, Bauer JT, Mills JN (2004) Ecologic and geographic distribution of filovirus disease. Emerging Infectious Diseases $10: 40-47$.

Philbey AW, Kirkland PD, Ross AD, Davis RJ, Gleeson AB, Love RJ, Daniels PW, Gould AR, Hyatt AD (1998) An apparently new virus (family Paramyxoviridae) infectious for pigs, humans, and fruit bats. Emerging Infectious Diseases $4: 269-271$.

Plowright RK, Eby P, Hudson PJ, Smith IL, Westcott D, Bryden WL, Middleton D, Reid PA, McFarlane RA, Martin G, Tabor GM, Skerratt LF, Anderson DL, Crameri G, Quammen D, Jordan D, Freeman P, Wang LF, Epstein JH, Marsh GA, Kung NY, McCallum H (2015) Ecological dynamics of emerging bat virus spillover. Proceedings of Biological Sciences 282 : 20142124. doi: 10.1098/rspb.2014.2124.

Pourrut X, Souris M, Towner JS, Rollin PE, Nichol ST, Gonzalez JP, Leroy E (2009). Large serological survey showing cocirculation of Ebola and Marburg viruses in Gabonese bat populations, and a high seroprevalence of both viruses in Rousettus aegyptiacus. BMC Infectious Diseases 9:159. doi: 10.1186/1471-2334-9-159.

Pringle CR (1991) The order Mononegavirales. Archives of Virology 117:137-140.

Raj VS, Farag EA, Reusken CB, Lamers MM, Pas SD, Voermans J, Smits SL, Osterhaus AD, Al-Mawlawi N, AlRomaihi HE, AlHajri MM, El-Sayed AM, Mohran KA, Ghobashy H, Alhajri F, Al-Thani M, Al-Marri SA, ElMaghraby MM, Koopmans MP, Haagmans BL (2014) Isolation of MERS coronavirus from a dromedary camel, Qatar, 2014. Emerging Infectious Diseases 20 :1339-1342. doi: 10.3201/eid2008.140663.

Reusken CB, Farag EA, Jonges M, Godeke GJ, El-Sayed AM, Pas SD, Raj VS, Mohran KA, Moussa HA, Ghobashy H, Alhajri F, Ibrahim AK, Bosch BJ, Pasha SK, Al-Romaihi HE, Al-Thani M, Al-Marri SA, AlHajri MM, Haagmans BL, Koopmans MP (2014) Middle East respiratory syndrome coronavirus (MERS-CoV) RNA and neutralising antibodies in milk collected according to local customs from dromedary camels, Qatar, April 2014. Euro Surveillance 19: 20829.
Reynes JM, Counor D, Ong S, Faure C, Seng V, Molia S, Walston J, Georges-Courbot MC, Deubel V, Sarthou JL (2005) Nipah virus in Lyle's flying foxes, Cambodia. Emerging Infectious Diseases 11:1042-1047.

Rihtaric D, Hostnik P, Steyer A, Grom J, Toplak I (2010) Identification of SARS-like coronaviruses in horseshoe bats (Rhinolophus hipposideros) in Slovenia. Archives of Virology 155 : 507-514. doi: 10.1007/s00705-010-0612-5.

Rota PA, Oberste MS, Monroe SS, Nix WA, Campagnoli R, Icenogle JP, Penaranda S, Bankamp B, Maher K, Chen MH, Tong S, Tamin A, Lowe L, Frace M, DeRisi JL, Chen Q, Wang D, Erdman DD, Peret TC, Burns C, Ksiazek TG, Rollin PE, Sanchez A, Liffick S, Holloway B, Limor J, McCaustland K, Olsen-Rasmussen M, Fouchier R, Gunther S, Osterhaus AD, Drosten C, Pallansch MA, Anderson LJ, Bellini WJ (2003) Characterization of a novel coronavirus associated with severe acute respiratory syndrome. Science 300:1394-1399.

Rubin J, David D, Willoughby RE Jr, Rupprecht CE, Garcia C, Guarda DC, Zohar Z, Stamler A (2009) Applying the Milwaukee protocol to treat canine rabies in Equatorial Guinea. Scandinavian Journal of Infectious Diseases 41 : 372375. doi: 10.1080/00365540902798333.

Rupprecht CE (2009) Bats, emerging diseases, and the human interface. PLoS Neglected Tropical Diseases 3 :e451. doi: 10.1371/journal.pntd.0000451.

Rupprecht CE, Gibbons RV (2004) Clinical practice. Prophylaxis against rabies. The New England Journal of Medicine 351:2626-2635.

Rupprecht CE, Smith JS, Fekadu M, Childs JE (1995) The ascension of wildlife rabies: A cause for public health concern or intervention? Emerging Infectious Diseases 1: 107-114.

Sazzad HM, Hossain MJ, Gurley ES, Ameen KM, Parveen S, Islam MS, Faruque LI, Podder g, Banu SS, Lo MK, Rollin PE, Rota PA, Daszak P, Rahman M, Luby SP (2013) Nipah virus infection outbreak with nosocomial and corpse-to-human transmission, Bangladesh. Emerging Infectious Diseases 19 :210-217. doi: 10.3201/eid1902.120971.

Schatz J, Teifke JP, Mettenleiter TC, Aue A, Stiefel D, Müller $\mathrm{T}$, Freuling CM (2014) Lyssavirus distribution in naturally infected bats from Germany. Veterinary Microbiology 169 : 33-41. doi: 10.1016/j.vetmic.2013.12.004.sss

Schountz T (2014). Immunology of Bats and Their Viruses: Challenges and Opportunities. Viruses $6:$ 4880-4901.

Schountz T, Green R, Davenport B, Buniger A, Richens T, Root JJ, Davidson F, Calisher CH, Beaty BJ (2004). Cloning and characterization of deer mouse (Peromyscus maniculatus) cytokine and chemokine cDNAs. BMC Immunology 5:1. 
Sendow I, Field H., Curran J, Darminto, Morrissy C, Meehan G, Buick T, Daniels P (2006) Henipavirus in Pteropus vampyrus bats in Indonesia. Emerging Infectious Diseases 12:711-712.

Song HD, Tu CC, Zhang GW, Wang SY, Zheng K, Lei LC, Chen QX, Gao YW, Zhou HQ, Xiang H, Zheng HJ, Chern SW, Cheng F, Pan CM, Xuan H, Chen SJ, Luo HM, Zhou HD, Liu YF, He JF, Qin PZ, Li LH, Ren YQ, Liang WJ, Yu YD, Anderson L, Wang M, Xu RH, Wu XW, Zheng HY, Cheng JD, Liang G, Gao Y, Liao M, Fang L, Jiang LY, Li H, Chen F, Di B, He LJ, Lin JY, Tong S, Kong X, Du L, Hao P, Tang H, Bernini A, Yu XJ, Spiga O, Guo ZM, Pan HY, He WZ, Manuguerra JC, Fontanet A, Danchin A, Niccolai N, Li YX, Wu CI, Zhao GP (2005) Cross-host evolution of severe acute respiratory syndrome coronavirus in palm civet and human. Proceedings of the National Academy of Sciences USA 102:2430-2435.

Streicker DG, Turmelle AS, Vonhof MJ, Kuzmin IV, McCracken GF, Rupprecht CE (2010) Host phylogeny constrains cross-species emergence and establishment of rabies virus in bats. Science 329 :676-679. doi: 10.1126/science. 1188836 .

Suin V, Nazé F, Francart A, Lamoral S, De Craeye S, Kalai M, Van Gucht S (2014) A two-step lyssavirus real-time polymerase chain reaction using degenerate primers with superior sensitivity to the fluorescent antigen test. Biomed Research International 2014:256175. doi $10.1155 / 2014 / 256175$.

Swanepoel R, Leman PA, Burt FJ, Zachariades NA, Braack LE, Ksiazek TG, Rollin PE, Zaki SR, Peters CJ (1996) Experimental inoculation of plants and animals with Ebola virus. Emerging Infectious Diseases 2:321-325.

Swinton J, Harwood J, Grenfell B, Gilligan C (1998) Persistence thresholds for phocine distemper virus infection in harbour seal Phoca vitulina metapopulations. Journal of Animal Ecology 67:54-68.

Timen A, Koopmans MP, Vossen AC, van Doornum GJ, Günther S, van den Berkmortel F, Verduin KM, Dittrich S, Emmerich P, Osterhaus AD, van Dissel JT, Coutinho RA (2009) Response to imported case of Marburg hemorrhagic fever, the Netherland. Emerging Infectious Diseases 15 :11711175. doi: 10.3201/eid1508.090015.

To KK, Chan JF, Tsang AK, Cheng VC, Yuen KY (2015) Ebola virus disease: a highly fatal infectious disease reemerging in West Africa. Microbes and Infection 17 :84-97. doi: 10.1016/j.micinf.2014.11.007.

Tong S, Li Y, Rivailler P, Conrardy C, Castillo DA, Chen LM, Recuenco S, Ellison JA, Davis CT, York IA, Turmelle AS,
Moran D, Rogers S, Shi M, Tao Y, Weil MR, Tang K, Rowe LA, Sammons S, Xu X, Frace M, Lindblade KA, Cox NJ, Anderson LJ, Rupprecht CE, Donis RO (2012). A distinct lineage of influenza A virus from bats. Proceedings of the National Academy of Sciences USA 109 :4269-4274. doi: 10.1073/pnas.1116200109.

Towner JS, Pourrut X, Albarino CG, Nkogue CN, Bird BH, Grard G, Ksiazek TG, Gonzalez JP, Nichol ST, Leroy EM (2007) Marburg virus infection detected in a common African bat. PLOS ONE 2: e764.

Turner DC (1975) The vampire bat. Johns Hopkins University Press, Baltimore, Md.

Van Thiel PP, de Bie RM, Eftimov F, Tepaske R, Zaaijer HL, van Doornum GJ, Schutten M, Osterhaus AD, Majoie CB, Aronica E, Fehlner-Gardiner C, Wandeler AI, Kager PA (2009) Fatal human rabies due to Duvenhage virus from a bat in Kenya: Failure of treatment with coma-induction, ketamine, and antiviral drugs. PLoS Neglected Tropical Diseases 3:e428. doi: 10.1371/journal.pntd.0000428.

Vijaykrishna D, Smith GJ, Zhang JX, Peiris JS, Chen H, Guan Y (2007) Evolutionary insights into the ecology of coronaviruses. Journal of Virology 81:4012-4020.

Wang HH, Kung NY, Grant WE, Scanlan JC, Field HE (2013) Recrudescent infection supports Hendra virus persistence in Australian flying-fox populations. PLoS One 8 :e80430. doi: 10.1371/journal.pone.0080430.

Warrilow D, Smith IL, Harrower B, Smith GA (2002) Sequence analysis of an isolate from a fatal human infection of Australian bat lyssavirus. Virology 297:109-119.

Willoughby RE Jr, Tieves KS, Hoffman GM, Ghanayem NS, Amlie-Lefond CM, Schwabe MJ, Chusid MJ, Rupprecht CE (2005) Survival after treatment of rabies with induction of coma. The New England Journal of Medicine 352:2508-2514.

Wong S, Lau S, Woo P, Yuen KY (2007) Bats as a continuing source of emerging infections in humans. Reviews in Medical Virology 17:67-91.

Woolhouse ME, Gowtage-Sequeria S (2005) Host range and emerging and reemerging pathogens. Emerging Infectious Diseases 11:1842-1847.

Yaiw KC, Bingham J, Crameri G, Mungall B, Hyatt A, Yu M, Eaton B, Shamala D, Wang L, Wong KT (2008) Tioman Virus, a Paramyxovirus of Bat Origin, Causes Mild Disease in Pigs and Has a Predilection for Lymphoid Tissues. Journal of Virology $82: 565-568$. 